\title{
Influence of Body Composition Measures about Cardiovascular Risks in the Elderly Practitioners of Physical Activity
}

Anna Cláudia Freire de Araújo Patrício1, Richardson Augusto Rosendo da Silva², Jiovana de Souza Santos ${ }^{3}$, Brenda Feitosa Lopes Rodrigues ${ }^{4}$, Ana Rebeca Soares de Medeiros ${ }^{4}$, Milenna Azevedo Minhaqui Ferreira ${ }^{4}$, Thays Domingos de Brito Rodrigues ${ }^{4}$, Géssica Thais de Sousa Nascimento ${ }^{4}$

\section{Abstract}

Objective: Analyze the influence of the measures body composition cardiovascular risk in elderly practitioners of physical activity.

Method: This is an exploratory study, transversal and quantitative. Held from May to June 2015, in the municipality of João Pessoa/Paraíba, with elderly patrons of sport aerobics. Were selected for the study 21 people, with inclusion criteria does not own metallic structure in the body to prevent the measure through bioimpedance equipment octopolar InBody 720 , less than 60 years of their own age and practice aerobics activity at least three months.

Results: Most of the individuals represented unfavorable health condition being more prone to cardiovascular risks. Identified that normal systolic blood pressure was the variable that most contributed to the score designed to show the possibility of a lower cardiovascular risk, while the visceral fat and fat-free mass were the factors that contributed for increased cardiovascular risk.

Conclusion: Optimization of preventive practices is necessary for cardiovascular diseases that propitiate the awareness of affected subject.
1 Ph.D. in Nursing for Nurse. Universidade Federal do Rio Grande do Norte. João Pessoa/Paraíba, Brazil.

2 Nurse. Assistant Professor, graduate program in nursing at the Federal University of Rio Grande do Norte. Rio Grande do Norte, Brazil.

3 Nurse. Master's degree in Nursing from the Federal University of Paraiba. João Pessoa/Paraíba, Brazil.

4 Bachelor of Nursing Student. Centro Universitário de João Pessoa. João Pessoa/Paraíba, Brazil.

Contact information:

Anna Cláudia Freire de Araújo Patrício.

झ claudia.freirearaujo@gmail.com 


\section{Introduction}

The chronic non-communicable diseases (NCD) constitute a serious public health problem in Brazil, and along with cardiovascular diseases, respiratory and feature high incidence in neoplastic elderly population. [1-2] thus, necessitating intensified in prevention in the elderly population, because the greater the number of risk factors, the greater the probability of presenting a cardiovascular event. [3]

Cardiovascular diseases (CVD) are the leading cause of morbidity and mortality in developed and emerging countries, this scenario persists even with changes in lifestyle and the numerous existing therapeutic processes. [4] In Brazil, the incidence of CVD grows over the years and, associated with this, the public expenditure on health supplements with the treatments have been progressively bigger. [5]

In this sense, the ageing of the population reflects a constant challenge for the health services working in the perspective of prevention, aiming to promote the increase of quality of life and reduce morbidities. [6] Promote healthy ageing world is no easy task, because it requires changes in the lifestyle of the population, and this includes the sedentary lifestyle. [7]

One of the consequences of physical inactivity, overweight, and is considered important in addition to the excess fat, its location, as it can cause Metabolic complications. The literature points to this variable as a cardiovascular risk factor, constituting its assessment essential in monitoring and targeting of actions aimed at health promotion, prevention and control of obesity and its Comorbidities. [8]

In this perspective, the studies to check the various cardiovascular risk factors should be accomplished. Thus, studying the influence of anthropometric standards with regard to cardiovascular risk factors are also important to evaluate how much of the modifications of these factors depend on changes in body composition. [9]

In Brazil, studies that assess the theme in question are still scarce, especially when it comes to elderly individual's practitioners of physical activities, justifying the conduct of this study.

To this end, information related to the influence of body composition measures about cardiovascular risks can collaborate on multidisciplinary approach to the health of the elderly, focused on prevention of complications related to cardiovascular diseases and for the development of public policies for healthy ageing.

On the exposed, this work aimed to evaluate the influence of body composition measures about cardiovascular risks in the elderly practitioners of physical activity.

\section{Methodology}

This is an exploratory study, transversal and quantitative. Held from May to June 2015, in the municipality of João Pessoa/Paraíba-Brazil, with elderly regulars of sport aerobics. Were selected for the study 21 people, aged 60 years or more, with inclusion criteria to participate in physical activity in water aerobics at least three months and not have the metallic structure in the body to prevent the measure through bioimpedance equipment octopolar InBody 720. Important to point out that in this study were considered elderly, as the status of the elderly that is regulated by law $10.741 / 2003$, those aged over 60 years, justifying the inclusion criterion. [10]

The blood pressure was checked by auscultation method, following rigorously the protocol proposed by the VI Brazilian Guideline of hypertension, [11] as advocated by the Brazilian Association of Cardiology/Brazilian Society of hypertension/Brazilian Society of Nephrology, using a sphygmomanometer aneroid (Missouri, Embu, São Paulo-Brazil), previously calibrated against a mercury column. The measurements were made at home (after $10 \mathrm{mi}-$ nutes sitting). For the measurement of the blood pressure was used a precision of two $\mathrm{mmHg}$, being considered as hypertension blood pressure greater 
than or equal systolic pressure 140 and diastolic pressure $90 \mathrm{mmHg}$.

The blood glucose rate was obtained by use of test strips in venous blood capillary (fingertip indicator), using disposable stilettos with instrumental reading of Optium Xceed Medi Sense. It was performed in 8-hour fasting and the desired value for the normal capillary blood glucose is at most 100 $\mathrm{mg} / \mathrm{dL}$. The value considered greater than or equal 126 milligrams per deciliter (mg/dL) will be considered high level, as the Brazilian of Dyslipidemias and Guideline V prevention of Atherosclerosis. [12]

The weight $(P)$, fat mass (MG), the area of visceral adiposity (AAV), fat-free mass (MIG) and skeletal muscle mass (MME) were evaluated with use of bioimpedance octopolar InBody 720 (Biospace, Seoul, Korea), with patients in 2 to 3 hours fasting and without practicing physical exercise in the hours leading up to the test preparations defined in the literature. [13] The InBody 720 uses 8 electrodes, being 2:00 pm contact with the Palm (E1 and E3) and thumb (E2 and E4) of each hand and 2:00 pm contact with the front part (E5 and E7) and heel (E6 and E8) of each foot, allowing to evaluate 4 compartments of body mass (total body water, proteins, minerals and fat mass). Five segmental impedances (right arm, left arm, torso, right leg and left leg). Several studies documenting the accuracy of this equipment in the estimation of total and segmental body composition. [14]

The data observed in this research were transposed to a spreadsheet in EXCEL and then converted to a file compatible with the statistical package Statistical Package for the Social Sciences (SPSS) that has enabled the preparation of statistical analyses with the models and techniques employed for the construction and validation of the scoring. Considering the normal category of blood glucose, blood pressure diastolic, systolic blood pressure, weight, visceral adiposity, fat-free mass and skeletal muscle mass was determined a score represented by the sum of these variables in dichotomized $1=$ Normal and $0=$ not normal. This naturally score ranges from 0 to 7. To assess the meaning of this indicator was a cluster analysis with Euclidean metric and connection method for hierarchical groupings. To evaluate the one-dimensionality of this score applied to factor analysis for dichotomous data determining the correlation matrix tetrachoric between the variables and then determined the eigenvalues of this matrix. It is also used for the ROC curve for classification of cardiovascular risk score.

The study was approved by the ethics and Research Committee of the Centro Universitário de João Pessoa/Paraíba, Brazil. CEP/UNIPÊ, CAEE: 38840214.7.0000.5176. All participants were asked to sign the informed consent (TFCC) in accordance with resolution 466/2012 National Health Council that governs the survey among human beings. [15]

\section{Results}

The demographic data of the participants of the study can be verified in the Table 1 .

Table 1. Demographic Data: sex, educational level, marital status and age. João Pessoa, PB. N $=21$.

\begin{tabular}{|l|c|c|}
\hline \multicolumn{1}{|c|}{ Variables } & N & $\%$ \\
\hline Sex & 20 & 95.2 \\
\hline Female & 1 & 4.8 \\
\hline Male & & \\
\hline Schooling & 1 & 4.8 \\
\hline Illiterate & 2 & 9.5 \\
\hline Elementary School & 10 & 47.6 \\
\hline High School & 8 & 38.1 \\
\hline Higher Education & & \\
\hline Marital status & 12 & 57.1 \\
\hline Married & 3 & 14.3 \\
\hline Single & 5 & 23.8 \\
\hline A widower & 1 & 4.8 \\
\hline Divorced & \multicolumn{2}{|c|}{$65.9 \pm 6.92$} \\
\hline Age (Medium age \pm SD) & SD = standard deviation \\
\hline
\end{tabular}


The meaning of the indicator on the blood glucose, blood pressure diastolic, systolic blood pressure, weight, visceral adiposity, fat-free mass and skeletal muscle mass, is represented in the dendrogram in Figure 1.

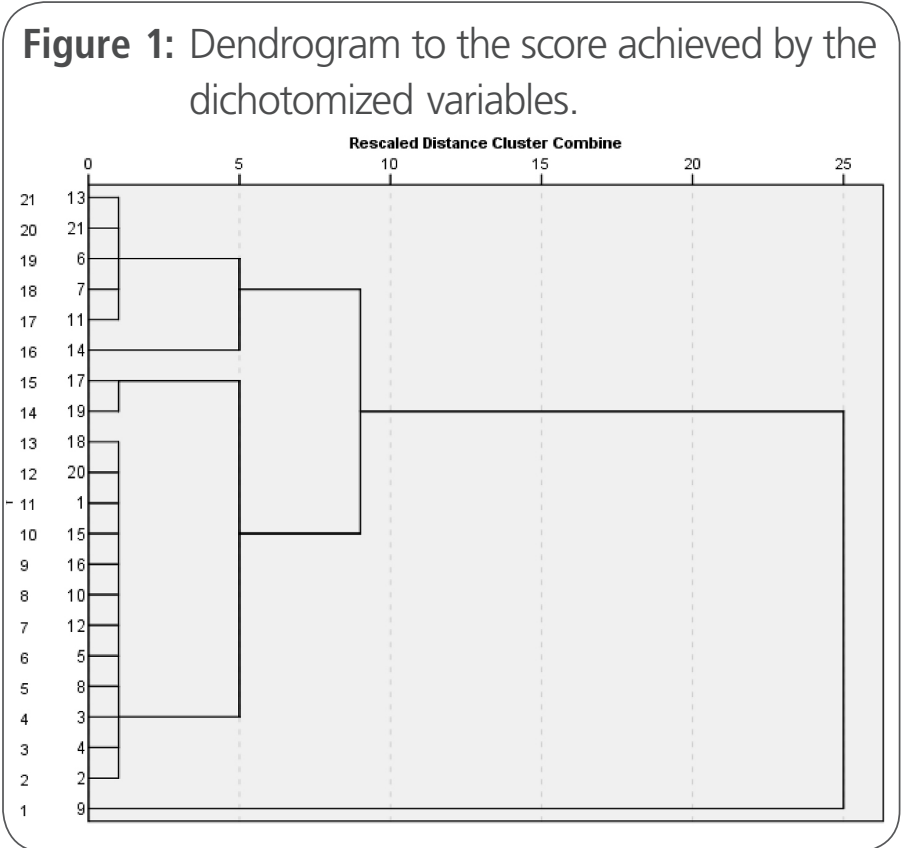

It can be observed in Figure 1 the clear formation of two groups: the first consisting of five individuals to the numbers in Figure designated $(6,7,11,13,21)$ and these have scores 2 and 3 respectively. That is, these individuals represent a condition unfavorable in terms of health and therefore more prone to cardiovascular risks since they represent the presence of the factors associated with an increase of this kind of risk. Therefore, values of this score less than or equal to three represents a greater risk of cardiovascular problems. It is observed that the individual is the 9 that has a lower cardiovascular risk.

To evaluate the one-dimensionality of this score applied to factor analysis for dichotomous data determining the correlation matrix tetrachoric between the variables and then determined the eigenvalues of this matrix. The first eigenvalue of this matrix presents explanatory power in relation to the total variance contained in the data equal to $42.6 \%$ featuring a strong influence of a single factor. Therefore, it can be considered that this score evaluates a one-dimensional construct that can be interpreted as the cardiovascular risk in the face of literature cited in presence of risk factors that were used in this work to the composition of this score.

For the variables on which it was possible to determine the risk of affect to values below 4 (score that means higher risk of cardiovascular disease), the results presented in Table 2 .

It is observed in Table $\mathbf{2}$ that the systolic blood pressure was normal the variable that most contributed to the score designed to show the possibility of a lower cardiovascular risk.

The classification of the score as quoted above was evaluated by ROC curve and $99.5 \%$ sensitivity and specificity $58.3 \%$ and is likely that in a larger sample these values can be larger.

Table 2. Risk of each variable calculated on the basis of the scores below 4 .

\begin{tabular}{|l|c|c|}
\hline \multicolumn{1}{|c|}{ Variable } & Risk & IC 95\% \\
\hline Systolic Blood Pressure & 0.031 & 0.002 to 0.420 \\
\hline Diastolic Blood Pressure & 0.400 & 0.036 to 4.411 \\
\hline Visceral fat & 0.867 & 0.711 to 1.057 \\
\hline Skeletal Muscle Mass & 0.154 & 0.017 to 1.369 \\
\hline Fat-free mass & 0.933 & 0.815 to 1.069 \\
\hline
\end{tabular}

\section{Discussion}

With regard to the demographic aspect identified that the average age of the elderly ranged from $65.9 \pm 6.92$ years, with $95.2 \%$ (20) female, $4.8 \%$ (1) male, most $57.1 \%$ (12) married, followed by $23.8 \%$ (5) widows, $14.3 \%$ (3) singles, $4.8 \%$ (1) divorced, with $47.6 \%$ high school (10), higher education $38.1 \%$ (8), 9.5\% complete primary school (2), illiterate $4.8 \%(1)$.

The female prevalence is related to greater longevity compared to men. However, the decrease in the fertility rate, is also related to the increase of the elderly population, as well as the female birth 
rate be greater compared to men, may explain the feminization of the sample. [16]

As for the level of education, there is a predominance of elderly with high school, followed by higher education. It's worth considering that the years of influence on social life, economy, and in the search for health services, constituting justification measures of public initiatives and non-governmental actions regarding literacy and continuing education of adults and the elderly. [17]

The low level of schooling may favor the policies of health risks, due to restrictions on access to information, as a result of the commitment of the skills of reading, writing and speaking, as well as the understanding of the complex mechanisms of disease and treatment. [18]

With regard to the health of individuals studied, the first group shown in Figure 1, shows an unfavorable condition in terms of health, thereby, increasing cardiovascular risks, since these individuals have one of the factors that increase the risk for cardiovascular disease.

With respect to the variables in which it was possible to determine the increased risk for cardiovascular disease (score below 4) are: systolic blood pressure, diastolic blood pressure, skeletal muscle mass, visceral fat, and fat-free mass. Noting that the fat-free mass and visceral fat have contributed more to the risk of disease.

Although the systolic blood pressure has constituted the most influential to the absence of risk, the monitoring and control of this variable, whereas the presence of systemic Arterial hypertension (SAH) contributes proportionately in the profile of Brazilian, where mortality predisposes the three leading causes of death: acute myocardial infarction, stroke and heart failure. [19]

The HAS it is a multifactorial clinical condition characterized by high and sustained levels of blood pressure. Associates often to functional changes and/or structural target organs (heart, brain, kidneys and blood vessels) and the metabolic changes, with increased risk of fatal and non-fatal cardiovascular events. [19]

Another risk factor found in this study encompasses the visceral fat that is present in the tissues, is an important influential for changes in metabolism, such as insulin resistance, type II diabetes, which can lead to hyperadrenergic state dyslipidemia, promoting the vasoconstriction of the muscles, raising your blood pressure and consequent increased sodium reabsorption. [20]

As a method of prevention of these factors has been the practice of physical activity with minimum frequency of five times a week, because it triggers a reduction of body weight and visceral fat, while preserving lean body mass, preventing excessive energy expenditure. [21]

Physical activity and nutrition are two behaviors considered priorities for health promotion and chronic disease prevention. Several institutions and organizations such as the American Heart Association, the World Health Organization and the American College of sports medicine, have emphasized the importance of the adoption of regular physical activity for the improvement of individual and collective health levels, especially for prevention and rehabilitation of Cardiovascular Disease. [22]

Body mass is an important determinant of the elevation of the PAS. A study conducted in a lowincome urban population (Fortaleza) concluded that the increased prevalence of SAH is directly proportional to the increase in body mass, that overweight and obese individuals have a prevalence of HAS $59 \%$ and $149 \%$ respectively greater than individuals with normal weight. [23]

In this sense, the main preventive measures are reducing the body weight, the intake of salt and alcohol consumption, the practice of physical exercises regularly and not using drugs that raise blood pressure. [19]

Another indicator assessed consisted in skeletal muscle mass, presenting significant risk value (0.154) for cardiovascular disease. The gradual loss 
of skeletal muscle mass and strength with the advancement of age, known as sarcopenia.

The sarcopenia is a generic term that indicates the loss of mass, strength and quality of the skeletal muscle and that has a significant impact on public health, has functional consequences on the floor and in the balance, increasing the risk of a fall and loss of physical functional independence, but also contributes to increase the risk of chronic diseases such as osteoporosis. [24]

The presence of sarcopenia is influenced by several factors that affect the quality and the amount of muscle mass, or may act as risk factors manifesting itself in physiological processes, changing body composition, causing the decline of the muscular system and the musculoskeletal system as a whole. [25]

In this way, the decline of the muscular system modifies the composition of the muscle fiber, with considerable reduction of innervation, the Vascularity of contractility and commitment of tendon units. [26]

On the exposed, the health team has the responsibility to identify cardiovascular risk factors and accompanying elderly people, considering the variables that affect the quality of life and that significantly influence on sustainability of cardiovascular diseases.

\section{Conclusion}

The research aimed to evaluate the influence of body composition measures about cardiovascular risks in the elderly practitioners of physical activity, being identified the visceral fat and fat-free mass as the most contributed factors for classification of the subject with greater risk cardiovascular.

It is observed that although the subjects investigated practice physical activity, were found problems that need to be reduced or resolved by implementing action strategies. However, this practice must be drawn up in collaboration and participation of the subjects involved in the process. Soon, the researchers propose the need for a method of intervention for this population.

It should be noted, as a limitation to the study, the possibility of reverse causality, typical in crosssectional studies, which does not allow to establish causal links safely between the events. However, the results identified in this research are awake for the indispensability of ways of optimization of outcomes of physical exercise programs intended for the elderly, guidelines and awareness process for cardiovascular risks.

\section{References}

1. Schmidt MI, Duncan BB, Azevedo SG, Menezes AM, Monteiro CA, Barreto SM, et al. Doenças Crônicas não Transmissíveis no Brasil: Carga e Desafios Atuais. Saúde no Brasil 4. 2011; (5): 6174.

2. Sociedade Brasileira de Cardiologia. IV Diretrizes Brasileiras sobre Dislipidemias e Prevenção da Aterosclerose do Departamento de Aterosclerose da Sociedade Brasileira de Cardiologia. Arq Bras. Cardiol. 2007; 88(1): 1-9.

3. Brasil. Ministério da Saúde. Datasus: indicadores de saúde. Brasília: 2015. Available from: http://www.datasus.gov.br

4. Garofolo L, Roberta SG. Ferreira FMJ. Estudo dos Fatores de Risco Associados à Arteriopatia Periférica em Nipo-brasileiros de Bauru (SP). Arq Bras. Cardiol. 2014; 102(2):143-150.

5. Correia BR, Cavalcante E, Santos E. A prevalência de fatores de risco para doenças cardiovasculares em estudantes universitários. Rev. Bras. Clin Med. 2010;8(1):25-9.

6. Almeida AHS, Santos SAG, Rodrigues Filho EA, Carvalho PRC, Batista GR. Somatotipo, Neto LG, Santana PVA, Mendes PC, Lima WKR, Navarro F. Treinamento resistido reduz riscos cardiovasculares em idosas. Rev. Bras. Med Esporte. 2015; 21(4):261-65

7. Organização Mundial de Saúde. Relatório Mundial de Envelhecimento e Saúde. OMS, 20 Avenue Appia, 1211 Genebra 27, Suíça, 2015.

8. Xavier FA, Barboza LF, Monteiro AMP, Santos LC, Oliveira DR. Fatores de risco cardiovascular entre docentes de uma universidade pública de minas Gerais. Rem. E - Rev. Min Enferm. 2010; 14(4): 465-72.

9. Patrício ACFA, Alves KL, Costa SMG, Duarte MCS, Rodrigues TP, Aguiar MSB. Medidas pressóricas, glicemia capilar, comorbidades e medicamentos autorreferidos por idosos. J res fundam care online. 2014; 6(2):676-84. 
10. Brasil. Presidência da República. Dispõe sobre o Estatuto do Idoso e dá outras providências. Casa Civil. Subchefia para Assuntos Jurídicos. Brasília. 2003. Available from: http://www. planalto.gov.br/ccivil 03/leis/2003/L10.741.htm

11. Brasil. Sociedade Brasileira de Hipertensão. VI Diretrizes Brasileiras de Hipertensão. Rev Bras. Hipertens. 2010; 17(1):760.

12. V Diretriz Brasileira de Dislipidemias e Prevenção da Aterosclerose. Arq Bras. Cardiol 2013; 101(4): 1

13. Chumlea WC, Sun SS. Bioelectrical impedance analysis. In: Heymsfield SB, Lohman TG, Wang Z, Going SB, editors. Human body composition. 2nd ed. Champaign: Human Kinetics Books; 2005. p. 79-88.

14. Fürstenberg $A$, Davenport $A$. Comparison of multifrequency bioelectrical impedance analysis and dual-energy X-ray absorptiometry assessments in outpatient hemodialysis patients. Am J Kidney Dis. 2011;57(1):123-9.

15. Brasil. Ministério da Saúde (BR). Resolução no 466, de 12 de dezembro de 2012. Dispõe sobre Pesquisas com Seres Humanos. Diário Oficial da União. Brasília, 2012.

16. Pilger C, Menon MH, Mathias TAF. Características sociodemográficas e de saúde de idosos: contribuições para os serviços de saúde. Rev. Latino Americana Enfermagem. 2011; 19(5): 9

17. Inouye K, Pedrazzani E. Nível de instrução, status socioeconômico e avaliação de algumas dimensões da qualidade de vida de octogenários. Rev. Latino-Am Enfermagem. 2007; 15(1): 74247.

18. Rodrigues FFL, Santos MA, Teixeira CRS, Gonela JT, Zanetti ML. Relação entre conhecimento, atitudes, escolaridade e tempo de doença em indivíduos com diabetes mellitus. Acta Paul Enferm. 2012; 25(2):284-90.

19. Sociedade Brasileira de Cardiologia. Departamento de Hipertensão Arterial. VI Diretrizes Brasileiras de Hipertensão Arterial. Rev. Bras. Hipertensão. 2010; 17(1): 1-64.

20. Pimenta IL, Sanches RC, Pereira JPR, Houri BF, Machado ELG, Machado FSG. Medidas das circunferências abdominal e cervical para mensurar riscos cardiovasculares. Rev. Med Minas Gerais. 2014; 24 (9):16-19.

21. Pitanga CPS, Pitanga FJG, Beck CC, Gabriel REC, Moreira MHR. Associação entre o nível de atividade física e a área de gordura visceral em mulheres pós-menopáusicas. Rev. Bras. Med Esporte. 2014; 20(4):252-56.
22. Oliveira CS, Stefane CA, Liziero L, Gabilan JG, Filho ACP, Guimarães FKO. A prática de atividade física na cidade universitária da Universidade Federal de Mato Grosso do Sul (UFMS). Ciênc saúde coletiva. 2011; 16(1):1489-96.

23. Feijão AMM, Gadelha FV, Bezerra AA, Oliveira AM, Silva MSS, Lima JWO. Prevalência de excesso de peso e hipertensão arterial, em população urbana de baixa renda. Arq. Bras.

24. VKR, Barros Neto TL. Impacto do envelhecimento nas variáveis antropométricas, neuromotoras e metabólicas da aptidão física. Rev Bras Ciên e Mov. 2000; 8(4).

25. Narici MV, Maffulli N. Sarcopenia: characteristics, mechanisms and functional significance. Br. Med. Bull 2010; 95(1):139-59.

26. Diz JBM, Queiroz BZ, Tavares LB, Pereira LSM. Prevalência de sarcopenia em idosos: resultados de estudos transversais amplos em diferentes países. Rev. Bras. Geriatr Gerontol. 2015; 18(3):665-78.
Publish in International Archives of Medicine

International Archives of Medicine is an open access journal publishing articles encompassing all aspects of medical science and clinical practice. IAM is considered a megajournal with independent sections on all areas of medicine. IAM is a really international journal with authors and board members from all around the world. The journal is widely indexed and classified Q1 in category Medicine. 